\title{
HAEMONCHUS CONTORTUS CON RESISTENCIA MÚLTIPLE A LOS ANTIHELMÍNTICOS DE CORTA Y LARGA ACCIÓN Y CONSIDERACIONES SOBRE EL IMPACTO SANITARIO-PRODUCTIVO DE ESTE FENÓMENO EN UNA MAJADA DE OVINOS LECHEROS DE LA PROVINCIA DE SANTA FE
}

\author{
Muchiut, S. ${ }^{1} ;$ Mildenberger, M. $^{1} ;$ Pujato, A. ${ }^{1}$ \& AnZiani, O. S. $^{2}$
}

\begin{abstract}
RESUMEN
Entre Octubre y Noviembre del 2012 se realizaron evaluaciones sobre la actividad de cuatro antihelmínticos con diferente mecanismo de acción (levamisol, ivermectina, closantel y febendazol) en ovinos lecheros naturalmente parasitados por nematodes gastrointestinales en un establecimiento del área central de Santa Fe. Las determinaciones de susceptibilidad o resistencia se realizaron a través del test de reducción en el conteo de huevos (TRCH) y como animales experimentales se utilizaron 40 corderos destetados de la raza Pampinta de aproximadamente dos meses y medio de edad. Estos animales fueron asignados a cuatro grupos de tratamientos de diez animales cada uno en función del número de huevos de nematodes por gramo de heces o hpg $(p>0,005)$. El TRCH se determinó estableciendo el porcentaje de reducción observado en el promedio del hpg en las muestras de materia fecal pre y post tratamiento de los mismos animales. Los resultados indicaron la presencia predominante de Haemonchus contortus con resistencia múltiple a ivermectina, febendazol y closantel así como de Nematodirus spp con resistencia a las dos primeras de estas drogas. El levamisol presentó una eficacia muy alta ( $>$ al $99 \%$ ) para controlar cualquiera de estos aislamientos. Ante la presencia de resistencia con los otros antihelmínticos, todos los corderos experimentales fueron re-tratados con levamisol observándose en este segundo TRCH una eficacia similar al primero. No obstante, debido a su baja actividad larvicida y su corta acción, aproximadamente 30 días posteriores al tratamiento de todos los corderos con levamisol se produjo un severo caso de haemonchosis con elevados índices de mortalidad.
\end{abstract}

Palabras clave: resistencia antihelmíntica múltiple, Haemonchus contortus, levamisol, Santa Fe.

1.- Facultad de Ciencias Veterinarias (UNL). Kreder 2805. (3080) Esperanza, provincia de Santa Fe. 2.- INTA EEA Rafaela. C.C. 22. (2300) Rafaela, provincia de Santa Fe.

Email: anziani.oscar@inta.gob.ar

Manuscrito recibido el 20 de agosto de 2013 y aceptado para su publicación el 13 de diciembre de 2013. 


\section{SUMMARY}

Between October and November 2012 a field trial was carried out in dairy sheep naturally parasitized by gastrointestinal nematodes in central Santa Fe (Argentina) to investigate the activity of four anthelmintic with different mechanism of action (levamisole, ivermectin, fenbendazole and closantel). The status of susceptibility or resistance was performed through the test of reduction in egg count (TRCH) on 40 Pampinta lambs about two and half months old. These lambs were assigned to four treatment groups of ten animals each according to the number of nematode eggs per gram of feces or hpg ( $\mathrm{p}>0.005)$. TRCH was determined by establishing the percentage reduction in the average observed epg in fecal samples before and after treatment of the same animals. The results indicated the predominance of Haemonchus contortus with multiple resistance to ivermectin, febendazole and closantel as well as Nematodirus spp with resistance to the first two of these drugs. Levamisole showed a very high efficacy (>99\%) to control any of these isolates. Due to the presence of Haemonchus spp with resistance to ivermectin, febendazole and closantel, all experimental lambs were re-treated with levamisole and similar efficacy in the TRCH was observed in this second trial. However, due to its low larvicidal activity and short action, approximately 30 days after levamisol treatment, a severe outbreak of acute haemonchosis with high mortality rates was observed.

Key words: multiple anthelmintic resistance, Haemonchus contortus, levamisol, Santa Fe.

\section{INTRODUCCIÓN}

El desarrollo creciente de la resistencia a los antihelmínticos por parte de los nematodes gastrointestinales representa un desafío a la sustentabilidad de la producción de pequeños rumiantes (Kaplan, 2004). En nuestro país por ejemplo, un estudio llevado a cabo en 2005 indicaba que en más del 60 $\%$ de las majadas (la provincia de Santa Fe no estuvo incluida), se observaban poblaciones de nematodes con resistencia hacia alguno de los antihelmínticos disponibles (Caracostantogolo et al., 2005). El problema de la resistencia es mayor en la región NEA y en la provincia de Corrientes el fenómeno se ha incrementado dramáticamente desde finales de la década del 90 a la actualidad en donde más de $85 \%$ de los establecimientos de ovinos muestran ineficacias en el control de los nematodes gastrointestinales (Romero et al., en prensa).

En la provincia de Santa Fe no existen estudios sobre la dispersión y magnitud de la resistencia antihelmíntica en ovinos. Los antecedentes documentados se limitan a un reporte involucrando al género Haemonchus spp resistente a los bencimidazoles (Eddi et $a l ., 1996)$ y a un reciente informe sobre este mismo género pero con resistencia antihelmíntica múltiple a cuatro grupos químicos distintos (Anziani \& Muchiut, 2012). El objetivo del presente estudio es actualizar y extender el conocimiento de estos fenómenos sobre un nuevo caso de resistencia múltiple a tres antihelmínticos por nematodes ovinos en la provincia de Santa Fe. En forma adicional se realizan observaciones sobre un severo caso de haemonchosis asociado a la resistencia y a los potenciales riesgos del uso 